\title{
DISTINÇÃO ENTRE USUÁRIO DE SERVIÇO PÚBLICO E CONSUMIDOR
}

\author{
ANTÔNIO CARLOS CINTRA DO AMARAL
}

1. Diferentemente da situação de consumo, a relação contratual entre concessionária e usuário, mediante a qual uma parte se obriga a prestar um serviço, recebendo em pagamento um preço público (tarifa), tem como pressuposto uma outra, entre a concessionária e o poder concedente. Em situações semelhantes a essa, a doutrina civilista italiana aponta a existência de dois contratos coligados, um, principal, o outro, acessório.

2. Por força do contrato principal - o de concessão —, a concessionária se obriga a prestar, ao usuário, "serviço adequado", definido pela Lei 8.987/95 (art. $6^{\circ}$ ) como "o que satisfaz as condições de regularidade, continuidade, eficiência, segurança, atualidade, generalidade, cortesia na sua prestação e modicidade das tarifas". Na hipótese de descumprimento do contrato de concessão, a concessionária está sujeita, conforme o caso: a) à aplicação de penalidades regulamentares e contratuais, inclusive multas: $b$ ) à intervenção na prestação de serviços; $c$ ) à extinção da concessão (caducidade).

3. A relação jurídica entre concessionária e usuário não pode ser equiparada à existente entre duas pessoas privadas, que atuam na defesa de seus interesses específicos. A prestação de "serviço adequado", embora delegada à concessionária, continua na titularidade e sob a responsabilidade do poder concedente. Perante a relação de consumo, diversamente, o Poder Público atua como "protetor" da parte considerada hipossuficiente, que, em regra, é o consumidor.

4. O tratamento dado ao usuário de serviço público pela Constituição e pela lei é diverso do dispensado ao consumidor. A Constituição chega mesmo a tratar dos dois assuntos em dispositivos diferentes: a concessão, no art. 175; a proteção ao consumidor, nos arts. $5^{\circ}$, inciso XXXII, e 170 , inciso V.

5. Vale notar, ainda, que o art. 27 da Emenda Constitucional ${ }^{\circ} 19 / 98$ determinou que o Congresso Nacional deverá elaborar "lei de defesa do usuário de serviços públicos". Isso equivale ao reconhecimento implícito de que essa defesa é juridicamente diversa da "defesa do consumidor", já regulada pela Lei 8.078/90. Salienta-se 
que essa lei deveria ter sido elaborada pelo Congresso Nacional no prazo de 120 (cento e vinte) dias, a partir de junho de 1998 .

6. Há vários projetos de lei tramitando no Congresso Nacional. Alguns determinam, equivocadamente, a aplicação subsidiária das normas da Lei 8.078 à defesa do usuário de serviço público. Isso servirá para perpetuar a confusão atual entre as duas relações jurídicas, a de serviço público e a de consumo. Cabe ao agora um outro código, diferente daquele, qual seja, o Código Defesa do Usuário de Serviço Público.

7. A defesa, pelo Poder Público, do usuário de serviço público é mais relevante do que a defesa do consumidor. $O$ pressuposto básico do instituto da concessão de serviço público no Direito brasileiro é a prestação de "serviço adequado". O princípio da indisponibilidade do interesse público, a que se refere Celso Antônio Bandeira de Mello em diversos escritos, impede que o poder concedente concorde com qualquer solução que prejudique essa prestação, por mínimo que seja o prejuízo, o que não ocorre na relação de consumo, em que os interesses envolvidos são privados.

8. A defesa do usuário de serviço público não é atribuição do PROCON, e sim da respectiva agência reguladora, cujo desafio atual é organizar-se adequadamente para isso. Como a lei prevista no art. 27 da Emenda Constitucional $n^{\circ} 19$ até hoje não foi aprovada pelo Congresso Nacional, o usuário de serviço público tem tido sua defesa calcada em uma lei (Lei 8.078) que claramente não se aplica à relação de serviço público, e sim à de consumo, conceitualmente diversa daquela.

9. Essa distinção conceitual pode ser graficamente exposta nos seguintes termos:

A) Relação de serviço público

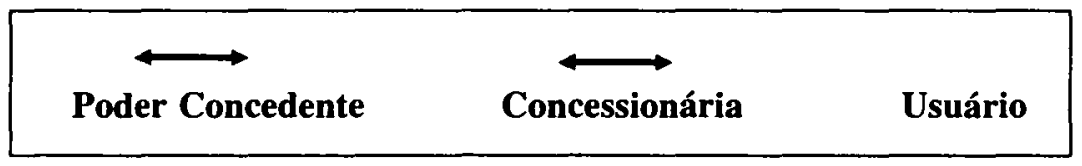

A concessionária é obrigada a prestar o serviço cujo exercício lhe foi atribuído, mas o poder concedente continua com o dever constitucional de prestá-lo, embora escolha a opção de fazê-lo indiretamente sob regime de concessão, como lhe é autorizado pelo art. 175 da Constituição. $O$ inadimplemento pela concessionária gera sua responsabilidade perante o usuário, mas também responsável é, solidariamente, o poder concedente.

B) Relação de consumo

\begin{tabular}{|c|c|}
\hline & Poder Público \\
\hline Fornecedor & Consumidor \\
\hline
\end{tabular}


O fornecedor é obrigado a prestar o serviço ao consumidor. O poder Público tem o dever de regular a relação contratual entre eles, protegendo a parte considerada mais fraca. $O$ inadimplemento pelo fornecedor gera sua responsabilidade perante $o$ consumidor. O Poder Público não é responsável pelo cumprimento das obrigações pelo fornecedor.

Concluindo: como recorda o jurista argentino Héctor Escola, "diz-se, com razão, que o grau de desenvolvimento e progresso de um país se mede pelo grau de organização e prestação de seus serviços públicos e a satisfação com que os usuários os utilizam". A prestação de "serviços adequado" - e o respectivo controle por agências reguladoras fortes e independentes - é fundamental. E quanto a isso tive oportunidade de escrever, em meu 'Concessão de Serviço 'serviço adequado' depende da consciência, pela concessionária, da função social a ela atribuída, da capacidade de gestão, pela Administração, e da organização dos respectivos usuários". 


\section{A Nova Família: Problemas e Perspectivas}

Organizador: Vicente Barretto

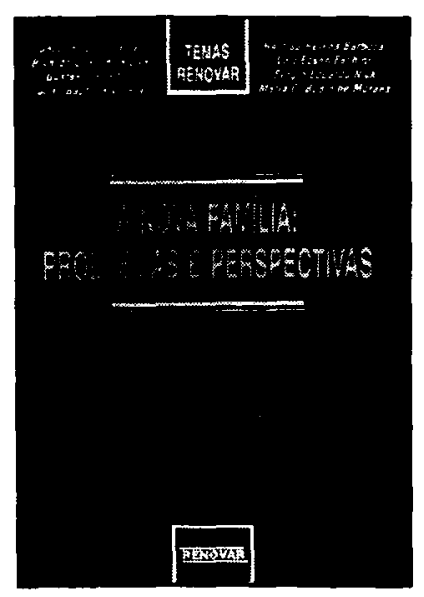

A reunião de textos sobre a "nova família", especialmente escritos por seus autores para a Coleçāo Temas Renovar, pretende trazer para a literatura jurídica brasileira novos métodos para a análise do fenômeno jurídico. Escolheu-se propositadamente um fato social - as novas formas de relações familiares -, que tem suscitado acalorados debates tanto entre juristas, como na opinião pública de uma forma geral, e que representa uma radical transformação no modelo de família, estabelecido no direito civil clássico.

Ref. $0146 \quad$ Brochura 198 págs. Form. 14x21 1997

\section{A Origem do Direito de Solidariedade}

José Fermando de Castro Farias

Este livro aborda temas centrais: a revolta contra o formalismo jurídico, direito e justiça, direito e experiência, os mecanismos jurídicos de gestão do social, o discurso solidarista, o paradigma da solidariedade e o solidarismo jurídico. Os enunciados do direito de solidariedade fazem parte de uma mesma formação discursiva, baseando-se em mecanismos comuns, cuja investigação passa por um estudo da História das Idéias Jurídicas, e, mais precisamente, por uma abordagem arqueológica do direito que remonta à Europa do fim do século XIX e do início do século XX.

Ref. 0166

Brochura

Form. 14x21 1998

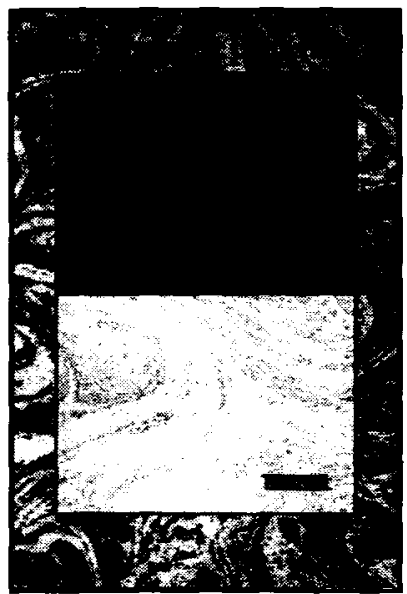

